\title{
Pengaruh Motivasi Kerja Dan Pendidikan Pelatihan Terhadap Kinerja Pegawai Pada PT. Indo Skin Jaya Utama Palembang
}

\author{
Adie Kurbani \\ Fakultas Ekonomi Universitas PGRI Palembang, \\ email: adie78kurbani@univpgri-palembang
}

\begin{abstract}
ABSTRAK
Penelitian ini bertujuan untuk mengetahui pengaruh motivasi kerja dan pendidikan pelatihan secara parsial maupun bersama-sama terhadap kinerja pegawai pada PT. Indo Skin Jaya Utama Palembang. Populasi dalam penelitian ini adalah seluruh pegawai PT. Indo Skin Jaya Utama Palembang yang berjumlah 148 orang. Sampel dalam penelitian ini merupakan data kuesioner pegawai PT. Indo Skin Jaya Utama Palembang Teknik analisis data yang dilakukan menggunakan metode analisis kuantitatif melalui program SPSS versi 22.

Berdasarkan hasil penelitian dapat diketahui bahwa ada pengaruh yang signifikan antara motivasi kerja dan pendidikan pelatihan secara parsial terhadap kinerja pegawai pada PT. Indo Skin Jaya Utama Palembang dengan nilai pengaruh sebesar 4,121 untuk variabel motivasi kerja dan sebesar 5,962 untuk variabel pendidikan pelatihan, dan untuk variabel motivasi kerja dan pendidikan pelatihan secara bersama-sama mempunyai pengaruh yang signifikan terhadap kinerja pegawai pada PT. Indo Skin Jaya Utama Palembang dengan nilai pengaruh sebesar 19,52. Hasil koefisien determinasi diperoleh nilai R square sebesar 0,407 atau 40,7\%. Hasil penelitian ini berarti bahwa $40,7 \%$ variasi variabel terikat yaitu kinerja pegawai dipengaruhi oleh variabel bebas yaitu motivasi kerja dan pendidikan pelatihan, sedangkan sisanya $59,3 \%$ dipengaruhi oleh faktor-faktor lain yang tidak diteliti.
\end{abstract}

\section{Kata Kunci : Motivasi Kerja, Pendidikan Pelatihan, Kinerja Pegawai.}

\section{A. Latar Belakang}

Sumber Daya Manusia merupakan komponen utama suatu organisasi yang menjadi perencana dan pelaksana dalam setiap aktivitas organisasi. Mereka mempunyai pikiran, perasaan, keinginan, status dan latar belakang pendidikan, usia, jenis kelamin yang heterogen yang di bawa ke dalam suatu organisasi sehingga tidak seperti mesin, uang dan material, yang sifatnya pasif dan dapat dikuasai dan diatur sepenuhnya dalam mendukung tercapainya tujuan organisasi. Sumber daya manusia, baik yang menduduki posisi pimpinan maupun anggota merupakan faktor tepenting dalam setiap organisasi atau instansi baik dalam organisasi atau instansi baik pemerintah maupun swasta. Hal ini karena berhasil tidaknya suatu organisasi atau instansi sebagian besar di pengaruhi oleh faktor manusia selaku pelaksana pekerjaan. Struktur organisasi adalah susunan komponenkomponen (unit-unit) kerja dalam organisasi. Struktur organisasi menunjukan adanya pembagian kerja dan menunjukan bagaimana fungsifungsi atau kegiatan-kegiatan yang berbeda-beda tersebut diintegrasikan (koordinasi). Selain itu struktur organisasi juga menunjukan spesialisasi-spesialisasi pekerjaan, saluran perintah, dan penyampaian laporan.

Salah satu kunci guna untuk mengembangkan organisasi secara efektif dan efisien adalah kinerja pegawai, untuk itu diperlukan pendidikan pelatihan (diklat) pegawai dan motivasi kerja untuk menambah pengetahuan dan mendorong pegawai bekerja lebih baik lagi terutama pada 
era globalisasi seperti saat ini dan adanya pasar bebas dimana tingkat persaingan pelayanan baik antar daerah maupun di dunia internasional. Untuk itu organisasi di tuntut untuk memiliki sumber daya manusia yang mempunyai pendidikan yang tinggi. Sehingga menghasilkan produktivitas yang tinggi atau kinerja pegawai yang dapat bersaing dalam mencapai tujuan di tempat ia bekerja.

Langkah-langkah yang diperlukan manajemen untuk meningkatkan kualitas kepegawaian agar memiliki keunggulan daya saing dan bekerja secara profesional adalah dengan melakukan program pemberdayaan pegawai dengan melakukan pendidikan pelatihan (diklat) pegawai, memberikan motivasi kerja, serta menempatkan pegawai pada posisi yang tepat. Hal ini akan memberikan manfaat bagi kantor salah satunya kinerja pegawai menjadi baik dan akan mendorong keuntungan bagi kantor tersebut.

Fenomena yang terjadi di PT. Indo Skin Jaya Utama Palembang adalah rendahnya motivasi kerja pegawai, hal tersebut dapat terlihat dari seringnya pegawai melakukan penundaan pekerjaannya, akibat yang ditimbulkan adalah pekerjaan pegawai tersebut menjadi terlambat untuk diselesaikan dan terjadinya penumpukan pekerjaan pegawai yang membuat waktu penyelesaian pekerjaan menjadi lebih lama, penyebab dari kurangnya motivasi kerja pegawai pada PT. Indo Skin Jaya Utama Palembang adalah kurang merata dan adilnya pelatihan yang diterima oleh pegawai PT. Indo Skin Jaya Utama Palembang. Fenomena lain yang terjadi pada PT. Indo Skin Jaya Utama Palembang adalah kurangnya pendidikan pelatihan dari pemerintah pusat, dan penunjukan peserta pendidikan pelatihan hanya di dapat oleh golongan tertentu.
Terkait dengan fenomena tersebut seharusnya PT. Indo Skin Jaya Utama Palembang mengusulkan kepada pemerintah pusat secara langsung ataupun tidak langsung agar menambah kuota bagi pegawai yang ingin mengikuti pendidikan pelatihan, dan penunjukan peserta pendidikan pelatihan tidak berdasarkan golongan tertentu sehingga seluruh pegawai PT. Indo Skin Jaya Utama Palembang dapat mengikuti pendidikan pelatihan secara adil dan merata, dan apabila hal tersebut dilakukan oleh PT. Indo Skin Jaya Utama Palembang akan menimbulkan motivasi pegawai untuk mengikuti pendidikan pelatihan, selanjutnya hasil dari pendidikan pelatihan tersebut diharapkan dapat menjadi bekal dan motivasi kerja pegawai dalam melaksanakan tugasnya sehingga kinerja pegawai tersebut menjadi baik.

\section{B. Rumusan Masalah}

Berdasarkan latar belakang masalah di atas yang menjadi rumusan masalah adalah :

1) Apakah Ada Pengaruh Motivasi Kerja Terhadap Kinerja Pegawai Pada PT. Indo Skin Jaya Utama Palembang?

2) Apakah Ada Pengaruh Pendidikan Pelatihan Terhadap Kinerja Pegawai Pada PT. Indo Skin Jaya Utama Palembang?

3) Apakah Ada Pengaruh Motivasi Kerja dan Pendidikan Pelatihan Terhadap Kinerja Pegawai pada PT. Indo Skin Jaya Utama Palembang?

\section{Metode Penelitian}

Peneliti menggunakan metode penelitian kuantitatif. Menurut Sugiyono (2014:7) penelitian kuantitatif dapat diartikan sebagai metode penelitian yang berdasarkan pada filsafat positivisme, digunakan untuk 
meneliti pada populasi atau sampel, teknik pengambilan sampel pada umumnya dilakukan secara random, pengumpulan data menggunakan instrumen penelitian analisis data bersifat kuantitatif / statistik dengan tujuan untuk menguji hipotesis yang ada.

\section{Populasi dan Sampel}

1) Populasi

Menurut Sugiyono (2014:80) populasi adalah wilayah generalisasi yang terdiri atas obyek/ subyek yang mempunyai kualitas dan karakteristik tetentu yang di tetapkan oleh peneliti untuk dipelajari kemudian di tarik kesimpulanya. Populasi dari penelitian ini adalah 148 orang pegawai tetap PT. Indo Skin Jaya Utama Palembang, maka populasi sebanyak 148 orang.

\section{2) Sampel}

Menurut Sugiyono sampel adalah bagian dari jumlah dan karakteristik yang dimiliki oleh populasi tersebut. Mengingat jumlah populasi pegawai lebih dari 100 orang yaitu sebanyak 148 orang pegawai, maka peneliti menggunakan rumus Slovin untuk menentukan sampel.

Rumus Slovin :

Dimana :

$$
n=\frac{N}{1+N e^{2}}
$$

n : Sampel

$\mathrm{N}$ : Jumlah Populasi

$\mathrm{Ne}^{2}$ : Tingkat Kesalahan Pengambilan Sampel (10\%)

Perhitunganya adalah:

$\mathrm{n}=\frac{148}{1+148(0,1)^{2}}=59,67$

Maka sampel yang digunakan peneliti adalah sebesar 60 pegawai tetap PT. Indo Skin Jaya Utama Palembang.

\section{E. Teknik Pengumpulan Data}

Teknik pengumpulan data dalam penelitian ini adalah :

1) Kuesioner merupakan teknik pengumpulan data yang di lakukan dengan cara memberi seperangkat pertanyaan atau pernyataan tertulis kepada responden untuk dijawabnya.

2) Dokumentasi yaitu mencari data mengenai hal-hal atau variabel yang berupa catatan, buku-buku, majalah, dokumen, peraturanperaturan, notulen rapat, catatan harian dan sebagainya.

\section{F. Teknik Analisis Data}

\section{Analisis Regresi Linier Berganda}

Menurut Kurniawan (2014:179) analisis regresi berganda adalah model persamaan regresi linier dengan variabel bebas lebih dari satu. Persamaan regresi dalam penelitian ini adalah untuk mengetahui seberapa besar pengaruh Motivasi Kerja dan Pendidikan Pelatihan terhadap Kinerja Karyawan.

Persamaan regresi berganda dirumuskan:

$Y=a+b_{1} X_{1}+b_{2} X_{2}$

Keterangan :

$\mathrm{Y}=$ Variabel Terikat Kinerja Pegawai

a = Bilangan Konstanta

$\mathrm{b}_{1}=$ Koefisien Motivasi Kerja

$\mathrm{X}_{1}=$ Variabel bebas Motivasi Kerja

$\mathrm{b}_{2}=$ Koefisien Pendidikan Pelatihan

$\mathrm{X}_{2}=$ Variabel Bebas Pendidikan Pelatihan

\section{Analisis Koefisien Korelasi}

Menurut Sugiyono (2014:276) analisis koefisien korelasi digunakan untuk membandingkan hasil pengukuran dua variabel yang berbeda agar dapat menentukan hasil hubungan antara variabel, 
Rumus koefisien korelasi adalah:

$$
r=\frac{n \sum X Y-\left(\sum X\right)\left(\sum Y\right)}{\sqrt{\left(n \sum(X)^{2}-\left(\sum X\right)^{2}\right)\left(n \sum(Y)^{2}-\left(\sum Y\right)^{2}\right)}}
$$

Keterangan :

$r$ : koefisien korelasi

$X$ : variabel Bebas

(Motivasi Kerja dan Pendidikan Pelatihan)

Y : Variabel Terikat (Kinerja Pegawai)

$\mathrm{n}:$ :Responden

$\Sigma$ : jumlah Responden (Sampel)

\section{Tabel 1}

\section{Interprestasi Koefisien Korelasi Nilai}

r

\begin{tabular}{|c|c|c|}
\hline No & $\begin{array}{c}\text { Interval } \\
\text { koefisien }\end{array}$ & $\begin{array}{c}\text { Tingkat } \\
\text { Hubungan }\end{array}$ \\
\hline 1 & $0,80-1,00$ & Sangat Kuat \\
\hline 2 & $0,60-0,80$ & Kuat \\
\hline 3 & $0,40-0,60$ & Agak Rendah \\
\hline 4 & $0,20-0,40$ & Rendah \\
\hline 5 & $0,00-0,20$ & Sangat Rendah \\
\hline
\end{tabular}

Sumber: Sugiyono 2014:277

\section{Koefisien Determinasi $\left(\mathbf{R}^{2}\right)$}

Menurut Siregar (2014:338) koefisien determinasi $\left(\mathrm{R}^{2}\right)$ adalah angka yang menyatakan atau digunakan untuk mengetahui kontribusi atau sumbangan yang di berikan oleh sebuah variabel atau lebih $X$ (Bebas) terhadap variabel $Y$ (Terikat). Adapun tekhnik analisis yang digunakan dalam pengujian koefisien determinasi dengan alat bantu menggunakan SPSS for windows versi 22 pada penelitian ini.

Rumus koefisien determinasi :

$$
R^{2}=(r)^{2} X 100 \%
$$

Keterangan :

$\mathrm{R}^{2}=$ Koefisien Determinasi

$r \quad=$ Kuadrat Koefisien Korelasi

\section{G. Hasil Penelitian}

\section{Analisis Regresi Linier Berganda}

Menurut Kurniawan (2014:179) analisis regresi berganda adalah model persamaan regresi linier dengan variabel bebas lebih dari satu. Persamaan regresi dalam penelitian ini adalah untuk mengetahui seberapa besar pengaruh Motivasi Kerja dan Pendidikan Pelatihan terhadap Kinerja Karyawan. Analisis Regresi Linier Berganda dilakukan menggunakan SPSS 22 for Windows yaitu dengan hasil :

Tabel 2

Coefficients $^{\mathrm{a}}$

\begin{tabular}{|c|c|c|c|c|c|c|}
\hline \multirow[b]{2}{*}{ Model } & & \multicolumn{2}{|c|}{ Unstandardized Coefficients } & \multirow{2}{*}{$\begin{array}{l}\text { Standardized } \\
\text { Coefficients } \\
\text { Beta }\end{array}$} & \multirow[b]{2}{*}{$\mathrm{t}$} & \multirow[b]{2}{*}{ Sig. } \\
\hline & & $\mathrm{B}$ & Std. Error & & & \\
\hline 1 & $\begin{array}{l}\text { (Constant) } \\
\text { motivasi kerja } \\
\text { pendidikan pelatihan }\end{array}$ & $\begin{array}{l}24,080 \\
, 183 \\
, 576\end{array}$ & $\begin{array}{l}5,261 \\
, 114 \\
, 139\end{array}$ & $\begin{array}{l}, 195 \\
, 509\end{array}$ & $\begin{array}{l}4,577 \\
1,597 \\
4,159\end{array}$ & $\begin{array}{l}, 000 \\
, 116 \\
, 000 \\
\end{array}$ \\
\hline
\end{tabular}

Hasil Regresi Linier Berganda

a. Dependent Variable: kinerja

Sumber : Hasil pengolahan data dengan Program SPSS Versi 22 tahun 2017.

Dari tabel diatas menunjukan hasil pandangan koefisien regresi dan pengujian secara parsial dengan $u j i$ berdasarkan tabel tersebut diperoleh nilai koefisien regresi untuk motivasi kerja dan nilai koefisien regresi untuk pendidikan pelatihan sebesar dan koefisien konstanta sebesar.
Berdasarkan nilai tersebut diperoleh persamaan regresi linier berganda adalah :

$$
\begin{aligned}
& y=a+X_{1}+X_{2}+X_{3} \\
& y=24,080+0,183 X_{1}+0,576 X_{2}
\end{aligned}
$$

Konstanta 24,080 artinya jika motivasi kerja $\left(\mathrm{X}_{1}\right)$ nilainya 0 dan 
Pendidikan pelatihan nilainya 0 , maka kinerja karyawan nilainya sebesar 24,080. Sedangkan koefisien regresi variabel regresi motivasi kerja $\left(\mathrm{X}_{1}\right)$ sebesar 0,183 artinya jika motivasi kerja mengalami kenaikan satu satuan, maka kinerja mengalami peningkatan sebesar 0,183 satuan dengan variabel independen lainnya bernilai tetap. Dan koefisien Pendidikan pelatihan 0,576 artinya jika pendidikan pelatihan mengalami kenaikan satu satuan, maka kineja pegawai akan mengalami peningkatan sebesar 0,576 satuan dengan asumsi variabel independen lainya bernilai tetap.

\section{Analisis Koefisien Korelasi}

Menurut Sugiyono (2014:276) analisis koefisien korelasi digunakan untuk membandingkan hasil pengukuran dua variabel yang berbeda agar dapat menentukan hasil hubungan antara variabel.

Hasil Koefisien Korelasi antara Motivasi Kerja dan Pendidikan Pelatihan terhadap Kinerja Pegawai adalah sebagai berikut

Tabel 3

Hasil Analisis Koefisien Korelasi

Model Summary
\begin{tabular}{|l|l|l|l|l|}
\hline Model & $\mathrm{R}$ & $\mathrm{R}$ Square & $\begin{array}{l}\text { Adjusted } \\
\text { R Square }\end{array}$ & $\begin{array}{l}\text { Std. Error of } \\
\text { the Estimate }\end{array}$ \\
\hline 1 &, $638^{\mathrm{a}}$ &, 407 & \multicolumn{3}{|c|}{, 386} & 2,98358 \\
\hline
\end{tabular}

Sumber : Hasil pengolahan data dengan Program SPSS Versi 22 tahun 2017.

Dari tabel di atas, dapat dilihat bahwa nilai koefisien korelasi (R) antara Motivasi Kerja $\left(\mathrm{X}_{1}\right)$ dan Pendidikan Pelatihan $\left(X_{2}\right)$ Terhadap Kinerja Karyawan (Y) adalah sebesar 0,63 . Sementara itu kriteria nilainya adalah sebagai berikut :

\section{Tabel 4}

\section{Interprestasi Koefisien Korelasi Nilai}

$r$

\begin{tabular}{|c|c|c|}
\hline No & Interval koefisien & Tingkat Hubungan \\
\hline 1 & $0,80-1,00$ & Sangat Kuat \\
\hline 2 & $\mathbf{0 , 6 0 - 0 , 8 0}$ & Kuat \\
\hline 3 & $0,40-0,60$ & Sedang \\
\hline 4 & $0,20-0,40$ & Rendah \\
\hline 5 & $0,00-0,20$ & Sangat Rendah \\
\hline
\end{tabular}

Sumber: Sugiyono 2014:277

Dari koefisien Korelasi ( $R$ ) yaitu sebesar 0,63 berarti berada pada range $0,60-0,80$. hal ini menunjukan bahwa korelasi antara motivasi kerja
$\left(X_{1}\right)$ dan pendidikan pelatihan $\left(X_{2}\right)$ terhadap kinerja karyawan $(\mathrm{Y})$ memiliki hubungan yang kuat.

\section{Koefisien Determinasi}

Menurut Siregar

(2014:338)

koefisien determinasi $\left(\mathrm{R}^{2}\right)$ adalah angka yang menyatakan atau digunakan untuk mengetahui kontribusi atau sumbangan yang di berikan oleh sebuah variabel atau lebih $X$ (Bebas) terhadap variabel $Y$ (Terikat). Teknik analisis yang digunakan dalam pengujian koefisien determinasi dengan alat bantu menggunakan SPSS for windows versi 22 tahun 2017 pada penelitian ini.

Hasil Koefisien Determinasi menggunakan SPSS for Windows Versi 22 tahun 2017 yaitu dengan hasil 
Tabel 5

Koefisien Determinasi

Model Summary
\begin{tabular}{|l|l|l|l|l|}
\hline Model & R & R Square & $\begin{array}{l}\text { Adjusted } \\
\text { R Square }\end{array}$ & $\begin{array}{l}\text { Std. Error of the } \\
\text { Estimate }\end{array}$ \\
\hline 1 &, $638^{\mathrm{a}}$ &, 407 &, 386 & 2,98358 \\
\hline
\end{tabular}

a. Predictors: (Constant), pendidikan pelatihan, motivasi kerja

Sumber : Hasil pengolahan data dengan Program SPSS Versi 22 tahun 2017.

Koefisien determinasi digunakan untuk mengetahui presentase sumbangan variabel independen secara bersama-sama terhadap varaiabel dependen. Jika koefisien korelasi berganda dikuadratkan diperoleh koefisien penentu berganda dengan melihat nilai $R$ square. Berdasarkan perhitungan model summary nilai adjusted square sebesar 0,407 sehingga dalam penelitian ini motivasi kerja dan pendidikan pelatihan dapat menjelaskan kinerja karyawan sampai 40,7 \% sedangkan 59,3\% sisanya dipengaruhi oleh variabel lain yang tidak diteliti dalam penelitian ini, seperti semangat kerja, disiplin kerja, kepuasan kerja, dan produktivitas kerja.

\section{Uji t}

Menurut Priyatno (2016:73) uji $t$ digunakan untuk mengetahui apakah variabel independen secara parsial berpengaruh terhadap variabel dependen. Uji t dalam penelitian ini menggunakan SPSS 22 for Windows.

Tabel 6

Uji t

Variabel Motivasi Kerja $\left(\mathrm{X}_{1}\right)$ terhadap Kinerja Pegawai $(\mathrm{Y})$ Coefficients $^{\mathrm{a}}$

\begin{tabular}{|c|c|c|c|c|c|c|}
\hline \multirow{2}{*}{\multicolumn{2}{|c|}{ Model }} & \multicolumn{2}{|c|}{ Unstandardized Coefficients } & \multirow{2}{*}{$\begin{array}{l}\text { Standardized } \\
\text { Coefficients } \\
\text { Beta }\end{array}$} & \multirow[b]{2}{*}{$\mathrm{t}$} & \multirow[b]{2}{*}{ Sig. } \\
\hline & & $\mathrm{B}$ & Std. Error & & & \\
\hline & $\begin{array}{l}\text { (Constant) } \\
\text { motivasi keria }\end{array}$ & $\begin{array}{l}34,998 \\
445\end{array}$ & $\begin{array}{l}5,159 \\
108\end{array}$ & 476 & $\begin{array}{l}6,783 \\
4,121\end{array}$ & $\begin{array}{r}000 \\
000\end{array}$ \\
\hline
\end{tabular}

a. Dependent Variable: kinerja

Sumber : Hasil pengolahan data dengan Program SPSS Versi 22 tahun 2017.

Uji t secara parsial untuk menguji pengaruh tiap variabel independen secara sendiri-sendiri (parsial) terhadap variabel dependen dengan membandingkan nilai thitung dengan $t_{\text {tabel. }}$ Jika $t$ hitung $<t$ tabel, maka variabel tersebut tidak berpengaruh secara signifikan. Jika $\mathrm{t}$ hitung $>\mathrm{t}$ tabel, maka variabel tersebut berpengaruh secara signifikan.

Nilai t tabel $\mathrm{N}=60-2=58$ dan alpha 0,05 adalah 2,001 . Sedangkan t sesuai tabel di atas adalah $\mathrm{X}_{1}=\mathrm{t}$ hitung 4,121 sehingga $>t$ tabel 2,000 , artinya motivasi kerja secara parsial berpengaruh secara signifikan terhadap kinerja pegawai. 


\section{Tabel 7 \\ Uji t}

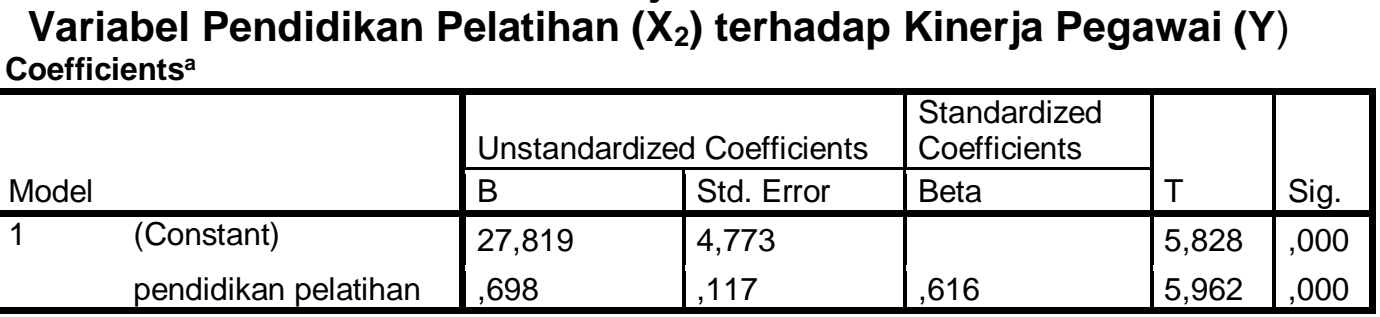

a. Dependent Variable: kinerja

Sumber : Hasil pengolahan data dengan Program SPSS Versi 22 tahun 2017.

Uji t secara parsial untuk menguji pengaruh tiap variabel independen secara sendiri-sendiri (parsial) terhadap variabel dependen dengan membandingkan nilai thitung dengan $t_{\text {tabel. }}$ Jika $t$ hitung $<t$ tabel maka variabel tersebut tidak berpengaruh secara signifikan. Jika $\mathrm{t}$ hitung $>\mathrm{t}$ tabel maka variabel tersebut berpengaruh secara signifikan.

Nilai t tabel $\mathrm{N}=60-2=58$ dan alpha 0,05 adalah 2,001 . Sedangkan t sesuai tabel di atas adalah $\mathrm{X}_{2}=\mathrm{t}$ hitung 5,962 sehingga $>t$ tabel 2,001, artinya pendidikan pelatihan secara parsial berpengaruh secara signifikan terhadap kinerja pegawai.

\section{Uji F}

Menurut Priyatno (2016:81) uji F digunakan untuk menguji apakah variabel independen secara simultan berpengaruh terhadap variabel independen.

Tabel 8

Uji F

ANOVA A $^{\text {Model }}$
\begin{tabular}{|ll|l|l|l|l|l|}
\hline Megression & Sum of Squares & Df & Mean Square & F & Sig. \\
\hline 1 & 347,585 & 2 & 173,793 & 19,523 &, $000^{\mathrm{b}}$ \\
& Residual & 507,398 & 57 & 8,902 & & \\
& Total & 854,983 & 59 & & & \\
\hline
\end{tabular}

a. Dependent Variable: kinerja

b. Predictors: (Constant), pendidikan pelatihan, motivasi kerja

Sumber : Hasil pengolahan data dengan Program SPSS Versi 22 tahun 2017.

Berdasarkan tabel di atas menjelaskan nilai $F$ hitung sebesar 19,523 , nilai $F_{\text {tabel }}$ di peroleh dengan melihat tabel nilai $f(\alpha=0,05)$ df2 $=60$ $3=57$ adalah 3,16 , maka nilai $F$ hitung $19,52>F$ tabel 3,16 . Nilai signifikasi $=$ $0.000<\alpha=0,05 \mathrm{H}_{0}$ di tolak dan $\mathrm{H}_{\mathrm{a}}$ di terima , artinya ada pengaruh signifikasi antara motivasi kerja dan pendidikan pelatihan terhadap kinerja pegawai.

Dari hasil analisis tersebut dapat di ketahui bahwa secara simultan variabel independen (motivasi kerja dan pendidikan pelatihan) ada pengaruh terhadap variabel dependen (kinerja pegawai). Sehingga hipotesis menyatakan variabel motivasi kerja dan pendidikan pelatihan secara simultan ada pengaruh secara signifkan terhadap kinerja pegawai pada PT. Indo Skin Jaya Utama Palembang.

\section{H. Pembahasan}

Berdasarkan nilai tersebut di peroleh persamaan linier berganda adalah $y=24,080+0,183 X_{1}+0,576 X_{2}$ dan nilai konstanta 24,080 artinya jika motivasi kerja $\left(\mathrm{X}_{1}\right)$ nilainya 0 dan Pendidikan pelatihan nilainya 0 , maka 
kinerja karyawan nilainya sebesar 24,080. Sedangkan koefisien regresi variabel regresi motivasi kerja $\left(X_{1}\right)$ sebesar 0,183 artinya jika motivasi kerja mengalami kenaikan satu satuan, maka kinerja mengalami peningkatan sebesar 0,183 satuan asumsi variabel independen lainya bernilai tetap. Dan koefisien Pendidikan pelatihan 0,576 artinya jika pendidikan pelatihan mengalami kenaikan satu satuan, maka kineja pegawai akan mengalami peningkatan sebesar 0,576 satuan dengan asumsi variabel independen lain nya bernilai tetap.

Berdasarkan perhitungan model summary nilai $R$ square sebesar 0,407 sehingga dalam penelitian ini motivasi kerja dan pendidikan pelatihan dapat menjelaskan kinerja karyawan sampai $40,7 \%$ sedangkan $59,3 \%$ sisanya dipengaruhi oleh variabel lain yang tidak diteliti dalam penelitian ini,seperti motivasi, semangat kerja, disiplin kerja, kepuasan kerja, dan produktivitas kerja.

Berdasarkan hasil analisis hipotesis $\mathrm{X}_{1}$ (Motivasi Kerja) ternyata ada pengaruh yang signifikan terhadap kinerja ini dapat dilihat dari $=\mathrm{t}$ hitung 4,121 sehingga $>t$ tabel 2,000 , artinya motivasi kerja secara parsial berpengaruh secara signifikan terhadap kinerja pegawai. Penelitian ini juga didukung oleh penelitian yang sudah dilakukan oleh Owin Syari pada tahun 2013 yang menyatakan bahwa ada pengaruh signifikan antara motivasi kerja terhadap kinerja pegawai dengan nilai uji $t$ hitung $(8,259)$ lebih besar dari $t$ tabel $(1,675)$.

Berdasarkan hasil analisis hipotesis $\mathrm{X}_{2}$ (Pendidikan Pelatihan) ternyata ada pengaruh yang signifikan terhadap kinerja ini dapat dilihat dari $t$ hitung 5,962 sehingga $>t$ tabel 2,000, artinya pendidikan pelatihan secara parsial berpengaruh secara signifikan terhadap kinerja pegawai. Penelitian ini juga didukung oleh penelitian yang sudah dilakukan oleh Dewi Anggriani pada tahun 2013 yang menyatakan bahwa ada pengaruh signifikan antara pendidikan pelatihan terhadap kinerja pegawai dengan nilai uji $t$ hitung $(7,023)$ lebih besar dari $t$ tabel $(2,021)$.

Dari hasil uji secara parsial menunjukan bahwa motivasi kerja berpengaruh secara signifikan terhadap kinerja pegawai karena $t$ hitung $>t$ tabel, begitu juga dengan pendidikan pelatihan berpengaruh secara signifikan terhadap kinerja pegawai karena $t$ hitung $>t$ tabel.

Dari pengujian hipotesis secara simultan variabel independen (motivasi kerja dan pendidikan pelatihan) ada pengaruh terhadap variabel dependen (kinerja pegawai). Sehingga hipotesis menyatakan variabel motivasi kerja dan pendidikan pelatihan secara simultan ada pengaruh secara signifikan terhadap kinerja pegawai, ini dapat dilihat dari nilai $F$ hitung $19,52>F$ tabel 3,16 . dengan Nilai signifikasi $=0,05$ dan probability 0.000 berarti Ho di tolak dan $\mathrm{H}_{\mathrm{a}}$ diterima.

\section{Kesimpulan dan Saran \\ 1. Kesimpulan}

Berdasarkan hasil penelitian dan pembahasan peneliti dapat menyimpulkan bahwa motivasi kerja dan pendidikan pelatihan berpengaruh terhadap kinerja pegawai pada PT. Indo Skin Jaya Utama Palembang. Hal ini terbukti bahwa meningkat dan menurunnya kinerja pegawai dipengaruhi oleh variabel motivasi kerja dan pendidikan pelatihan. Penelitian ini membuktikan hipotesis yang menyatakan bahwa:

a) Ada pengaruh yang signifikan antara motivasi kerja terhadap kinerja pegawai pada PT. Indo Skin Jaya Utama Palembang dengan nilai pengaruh sebesar 4,121 . 
b) Ada pengaruh yang signifikan antara pendidikan pelatihan terhadap kinerja pegawai pada PT. Indo Skin Jaya Utama Palembang dengan nilai pengaruh sebesar 5,962.

c) Ada pengaruh yang signifikan antara motivasi kerja dan pendidikan pelatihan secara bersama-sama terhadap kinerja pegawai pada PT. Indo Skin Jaya Utama Palembang dengan nilai pengaruh sebesar 19,52 .

\section{Saran}

Berdasarkan kesimpulan yang telah diuraikan, maka saran yang dapat peneliti sampaikan adalah sebagai berikut:

a) Motivasi kerja pada PT. Indo Skin Jaya Utama Palembang ini sudah cukup baik. Namun perlu untuk ditingkatkan lagi, misalnya dengan dilibatkanya pegawai dalam pembuatan keputusan oleh pimpinan.

b) Pendidikan Pelatihan pada PT. Indo Skin Jaya Utama Palembang perlu ditingkatkan lagi dengan mengusulkan kepada pemerintah pusat secara langsung ataupun tidak langsung agar menambah kuota bagi pegawai yang ingin mengikuti pendidikan pelatihan dan penunjukan peserta pendidikan pelatihan tidak berdasarkan golongan tertentu sehingga seluruh pegawai Distrik Navigasi Kelas I Palembang dapat mengikuti pendidikan pelatihan secara adil dan merata selain itu pendidikan pelatihan harus dilakukan sesuai dengan kebutuhan pegawai.

c) Untuk meningkatkan kinerja Pegawai pada PT. Indo Skin Jaya Utama Palembang, pimpinan harus memberikan motivasi kepada pegawai dan memberikan pengarahan tentang apa tujuan dari pekerjaan yang pegawai lakukan.

\section{DAFTAR PUSTAKA}

Anggriani, Dewi. 2012. Pengaruh Pendidikan dan Pelatihan Terhadap Kinerja Pegawai pada Badan Arsip Daerah Provinsi Sumatera Selatan. Skripsi FE Universitas PGRI Palembang (tidak untuk di publikasikan).

Hardiansyah. $\quad 2012 . \quad$ Sistem Administrasi dan Manajemen Sumber Daya Manusia Sektor Publik. Jakarta: Gava Media.

Hasibuan, Malayu. 2011. Manajemen Kepemimpinan Teori dan Aplikasi. Bandung: CV. Alfabeta.

Kurniawan, Albert. 2014. Metode Riset Untuk Ekonomi dan Bisnis. Bandung: CV Alfabeta.

Manullang. 2011. Manajemen Personalia. Yogyakarta: Universitas Gajah Mada.

Notoatmodjo, $\quad$ Soekidjo. 2015. Pengembangan Sumber Daya Manusia. Cetakan ke 5. Jakarta: Rineka Cipta.

Priyatno, Duwi. 2014. Belajar Alat Analisis dan Pengelolaanya Dengan SPSS. Yogyakarta: Gava Media.

Siregar, Syofian. 2013. Statistik Parametrik Untuk Penelitian Kualitatif. Jakarta: Bumi Aksara.

Sugiyono. 2014. Metode Penelitian kuantitatif,kualitatif dan $R \& D$. Cetakan ke 20. Bandung : CV. Alfabeta. 
Syari, Owin. 2013. Pengaruh Motivasi Kerja Terhadap Kinerja Pada Kantor Direktorat Universitas Sriwijaya di Indralaya. Skripsi FE
Universitas PGRI Palembang (tidak untuk di publikasikan).

Wibowo. 2014. Manajemen Kinerja. Edisi Ke 4. Jakarta: PT Raja Grafindo Persada. 